\title{
Sustainable Community-Based Tourism Village Development Strategy in Fatumnasi Village of South Central Timor Regency East Nusa Tenggara
}

\author{
Melky Kabu*, Sari Bandaso Tandilino \\ Travel Business Study Program \\ State Polytechnic of Kupang \\ Kupang, Indonesia \\ *melkykabu@pnk.ac.id
}

\begin{abstract}
The sustainability of tourism development must be supported by the management of all existing resources evenly so that all social and economic needs can be met by maintaining local culture, environmental preservation, and diversity of people's lives. And sala one way of sustainable tourism development is community-based tourism development (CBT). The purpose of this research was to find out the strategy of development of CBT-based tourism villages in Fatumnasi Village, South Central Timor Regency. Data analysis techniques used and analysis of the internal and external conditions of Fatumnasi Village, as well as the suitability of the nature between the expectations and desires of the people as well as tourists. Fatumnasi tourism village is one of the seven plantation tourist sites established by the Government of East Nusa Tenggara Province where $90 \%$ of fatumnasi villagers strongly agree to carry out community-based tourism and swot analysis results result in SO strategy, WO strategy, ST strategy and WT strategy.
\end{abstract}

Keywords-tourism village, community-based tourism, sustainable

\section{INTRODUCTION}

One form of participatory planning in tourism development is to implement Community Based Tourism (CBT) as a development approach. CBT definition is: 1) a form of tourism that gives local people the opportunity to control and engage in the management and development of tourism, 2) people who are not directly involved in any tourism business also have the opportunity to profit, 3) demand empowerment in terms of benefits for disadvantaged communities in the village.

Community based tourism (CBT) is a model of tourism development that prioritizes community participation in tourism development. CBT concept places the community as the main culprit through community empowerment in various tourism activities, so that the benefits of tourism are fully owned by the local community.

CBT is a concept that emphasizes community empowerment to better understand and appreciate all the tourism potential that exists in its place such as culture, customs, culinary, residence and also other natural resources. CBT is a tourism development activity that involves the community, where the planning of activities, management, and supervision is entirely controlled by the community. Thus, the role of the community as stakeholders is a very important element in the development of tourist villages.

The average visit of foreign tourists (tourists) to Indonesia in the last five years (2014-2018) increased from 9.43 million people to 15.81 million people. The increasing number of Indonesian governments continues to improve. Infrastructure development and promotion of tourist destinations to become destinations for local and central governments to attract more tourists. For Indonesia, tourism is one of the most promising sectors. The government and the Tourism Office are working to improve the tourism industry. So tourism in Indonesia has its own appeal, as well as having the selling power of the international economy. Certainly by improving the service, quality and quality of Indonesia's tourism sector. Indonesia has many interesting and must-visit destinations, it is spread across various provinces in Indonesia. One of them is East Nusa Tenggara Province (NTT).

Fatumnasi nature reserve located in Fatumnasi Village is famous for its beautiful scenery because it is at an altitude of 1200 dpl. Fatumnasi sub-district of South Central Timor regency is one of 32 sub-districts with a population of 6,869 that has 5 villages, 13 hamlets, $30 \mathrm{RW}$ and $61 \mathrm{RT}$ with an area of 194,658 Km2. Geographically, Fatumnasi sub-district is at an altitude of 1200-1800 dpl. Geonologically fatumnasi subdistrict is to the north bordering TTU Regency, to the south bordering North Mollo Sub-District, to the east bordering Tobudan sub-district to the west with Nunbena sub-district and Kupang regency. The area is at an altitude of 1200-1800 above sea level with an average temperature of 16-200C and a humid tropical climate. The area of Fatumnasi sub-district is 195.65 $\mathrm{km} 2$ which is divided into forest areas of fatumnasi nature reserves and residential areas. 
The residential area is divided into 5 villages namely Fatumnasi Village, Nenas Village, Mutis Village, Kuanoel Village, and Nuapin Village. In Fatumnasi Village there are 10 rooms available in a Homestay consisting of 10 Lopo buildings (dawan traditional houses) managed by Mr. Mateos Anin in Fatumnasi Village. Currently the management of the homestay is still in the form of family management, so this business faces many obstacles in its marketing. Lopo residents in Fatumnasi Village and many other villages have been built by Lopo so that in the future it can be used as a homestay for tourists who come. In addition, a souvenir business has been established in the form of the manufacture of woven fabrics whose product types vary such as woven fabrics, sarongs, scarves, hats, betel bags and other typical Dawan souvenirs made of lontar leaves.

But the involvement of fatumnasi villagers directly in the activities of managing tourist destinations is still very far from expectations. For example, for homestay businesses, only one person can do it. In addition, tourism aware groups do not run as they should, people still do not understand and understand about tourism awareness. In fact, the potential of Fatumnasi Village is very promising to be developed with a pattern of community partnership known as community based tourism (CBT). The management of tourist destinations in cbt-based tourist villages prioritizes the mastery of economic activities such as food stalls, mentors, homestay management, the manufacture of local souvenirs must be done all by the people of Fatumasi Village, in addition the community is also attempted.

\section{A. Formulation of Problems}

How to develop community-based tourism village in Fatumnasi Village, South Central Timor Regency.

\section{B. Research Objectives}

To find out the strategy of developing community-based tourism villages in Fatumnasi Village, South Central Timor Regency.

\section{Benefits of Research}

East Nusa Tenggara province has a vision and mission that targets by 2020 has more than 1,000 tourist villages in 22 districts / cities in the island province. Related to this, this research will contribute to the District Government of South Central Timor to implement a model of tourism-based tourism development strategy based on tourism where the community is not only an object of development in the village itself but also as a tourism agency. With the multiflier effect, it is hoped that the development of tourist villages can also reduce the number of poor people, reduce urbanization and send labor abroad so that the welfare of the people and regional income can increase in South Central Timor district.

\section{LITERATURE REVIEWS}

\section{A. DefInition of Rural Tourism}

Tourism village is one form of application of tourism development based on community and sustainable. Inskeep very well reveals that tourist villages are a form of tourism, where a small group of tourists live in or near traditional community life or in remote villages and learn about village life and the local environment [1]. Related to the concept of tourism village development, Pearce defines the development of tourist villages as a process that emphasizes ways of developing or advancing tourist villages [2]. More specifically, the development of tourist villages is interpreted as an effort to complement and improve tourism facilities to meet tourism needs.

The tourist village is a form of integration between attractions, accommodation and supporting facilities presented in a community living structure that integrates the prevailing ordinances and traditions [3].

Based on the type of tourism potential that has been the main element in attracting tourist visits, The Tourism Village can be distinguished into 4 types according to the Ministry of Tourism of the Republic of Indonesia, namely:

- Tourism Village Based on The Uniqueness of Natural Resources as The Main Tourist Attraction.

- Tourism Village Based on The Uniqueness of Local Cultural Resources as The Main Tourist Attraction.

- Unique Activity-Based Tourism Village/Creative Works as The Main Tourist Attraction.

- Combined Based Tourism Village (Unique Natural Resources, Local Cultural Resources, and Activities / Creative Works) as a Tourist Attraction Namely The Combination of Natural Resources and Local Cultural Resources, Combined Local Cultural Resources and Activities / Creative Works and A Combination of Natural Resources, Local Cultural Resources and Activities / Creative Works.

UNWTO said that sustainable development must a there to 3 (three) principles, namely: Ecological Sustainability, Social and Cultural Sustainability, and Economic Sustainability, both for current and future generations. In addition to the sustainability of natural and economic resources, cultural sustainability is a very important resource in tourism development. Tourism sustainability will be achieved if there is a sustainable use of natural resources, cultural resources, and human resources, as well as fair and equitable economic sustainability [4].

\section{B. DefInition of Community Based Tourism}

The CBT concept first emerged around the 1970s due to criticism of the negative impact sparked by mass tourism. Then got more attention in 2000, when the World Bank began thinking about how to solve the problem of poverty through the 
tourism sector which became known as community based tourist or CBT. Furthermore, three tourism activities are identified that can support the concept of CBT, namely adventure tourism, cultural tourism, and ecotourism.

Community-based tourism is increasingly seen as a more sustainable alternative, as it emphasizes the active involvement of local communities and their control over tourism development. Marinovski in Kustini [5] said community-based tourism (CBT) is increasingly considered a more sustainable alternative, as it emphasizes the active involvement of local communities and their control over tourism development. The concept of Community Based Tourism or Community Based Tourism abbreviated as CBT is the concept of developing tourist destinations through the empowerment of local communities. Where the community contributes to the planning, management and delivery of opinions [6]. Community Based Tourism (CBT) is a tourism that pays attention to environmental, social and cultural sustainability aspects. CBT is a tool for community development and environmental preservation or in other words CBT is a tool for sustainable tourism development [7]. One of the representations of community-based tourism development is tourism village.

While according to Hudson in Timothy [8] the special characteristic of community based tourism is related to the benefits obtained and the efforts of mentoring planning that defend local communities and other groups have an interest/ interest, which gives greater control in the social process to realize welfare.

The concept of CBT first emerged around the 1970s due to criticism of the negative impact sparked by mass tourism. Then it gained more attention in 2000, when the World Bank began to think about how to tackle the problem of poverty through the tourism sector which became known as "community-based tourism" (CBT). Furthermore, there are three tourism activities that can support the concept of CBT, namely adventure travel, cultural travel and ecotourism.

REST states that CBT is a tourism that focuses on the environment, social community, and cultural continuity in one development focus [7]. CBT is managed and owned from and by the community, with the aim of giving tourists knowledge of how local wisdom and daily life are conducted in the community.

There are 5 principles of community-based tourism development namely [7]:

- The economic dimension, with indicators in the form of funds for community development, the creation of jobs in the tourism sector, the rise of local people's income from the tourism sector.

- Social dimension with indicators of rising quality of life, increased community pride, fair role sharing between women, young and old generations, building strengthening community organizations.
- The cultural dimension with indicators in the form of encouraging people to respect different cultures, helping to develop cultural exchanges, cultural development is closely inherent in the local culture.

- Environmental dimensions, with indicators of studying carrying capacity area, regulating waste disposal, raising awareness of the need for conservation.

- Political dimension, with indicators: increasing participation of the local population, increasing the power of the wider community, guaranteeing rights in the management of natural resources.

\section{DefInition SWOT Analysis (Strengths, Weaknesses, Opportunities, and Threats)}

SWOT analysis is a strategic planning method used to evaluate strengths, weaknesses, opportunities and threats. This analysis is based on the assumption that an effective strategy comes from a good "conformity" between the organization's resources (strengths and weaknesses) and external situations (opportunities and threats). A good match maximizes organizational strengths and opportunities while minimizing weaknesses and threats. If applied accurately, these simple assumptions have both implications and deep lying of a successful strategy design [2].

Sari Bandaso research study [9] on the development of tourist villages in Fatumnasi Village should be conducted through a complete interaction model meaning the concept of community based tourism needs to be applied. In addition, the application of community based tourism in Lamalera Village, B Lembata Sub-District [9] concluded that the application of the dimensions of community based tourism will be able to improve the welfare of the people in the tourist village.

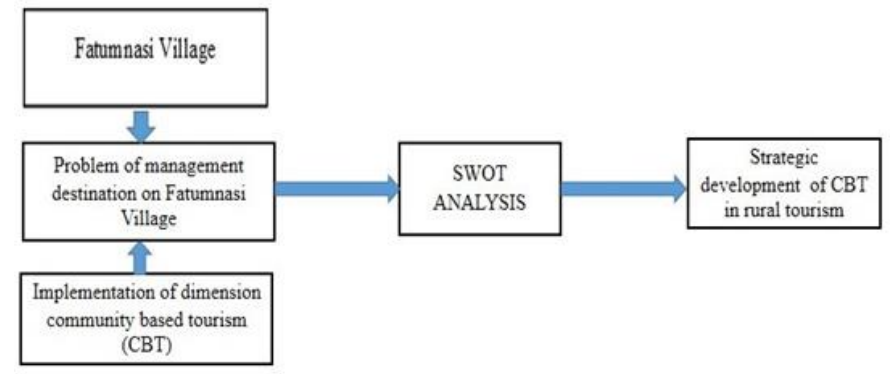

Fig. 1. Research framework for thinking.

\section{RESEARCH METHODS}

The research site was conducted in Gunung Mutis Nature Reserve precisely in Fatumnasi Village fatumnasi sub-district of South Central Timor Regency. The research instrument used for data collection in this study is; a. Questionnaire attitude to the community to get information about the attitude of fatumnasi villagers in the application of community-based tourism that has been implemented based on economic, social, cultural, environmental and political dimensions. Attitude level scale is done by added method or scale rating [10]; b. 
Importance-Performance Analysis Questionnaire to find out the relationship between interest level and cbt dimension implementation performance assessed by tourists visiting Fatumnasi Village; C. In-depth interviews with the community, village chiefs, tourism awareness groups, TTS and NTT district government as well as tourists are a way to get information through data by holding live questions between researchers and parties that can help provide additional information. At this stage of the interview is used SWOT analysis testimonial form.

Primary data is data obtained from answers given by respondents through questionnaires and in-person interviews with the public, tourism aware groups (Pokdarwis), and tourists visiting Fatumnasi Village and secondary data is data obtained to support this research such as tourist visit data, plantation tourism and others.

The subject of the study according to Arikunto [11] is something that is very important position in the study, the subject of the study must be arranged before the researcher is ready to collect data. Research subjects can be objects, objects or people. Thus the subject of research in general is human or whatever is human affairs. So the subjects in this study are the people of Fatumnasi Village and tourists who visited and the object in this study is something that is the focus of research activities or in other words everything that is targeted by research [10] so that the research object of this lesson.

The population in this study is the Head of Tourism Office of NTT District Tourism Office. TTS, sub district head Fatumnasi, Fatumnasi Village Community, Tourism Aware Group (POKDARWIS), indigenous figures / people and tourists in Fatumnasi Village due to its large population then researchers drew purposive sampling samples as many as 50 samples.

\section{A. Data Analysis Techniques}

This descriptive qualitative research uses the SWOT Matrix as a subjective analysis tool for business information classified into four sections to aid understanding, presentation, discussion and decision making. The four dimensions of the matrix divide the advantages and disadvantages and then bring them together with internal factors and external factors.

This matrix is capable of producing four sets of possible strategies as described below.

- SO strategy (Strengths - Opportunities) strategy is to use all the power to seize and take advantage of the greatest opportunities in community-based tourism development.

- ST strategy (Strengths - Threats) is a strategy in using the powers it has to address threats in the development of community-based tourism.

- WO Strategy (Weaknesses - Opportunities) strategy, this strategy is implemented based on existing opportunities by minimizing existing weaknesses for community-based tourism development.
- WT Strategy (Weakness-Threat) strategy, this strategy is based on defensive activities and seeks to minimize existing weaknesses and avoid threats with the aim of developing community-based tourism.

\section{THE RESUlTS OF RESEARCH}

Fatumnasi sub-district of South Central Timor regency is one of 32 sub-districts with a population of 6,869 that has 5 villages, 13 hamlets, $30 \mathrm{RW}$ and $61 \mathrm{RT}$ with an area of 194,658 Km2. Geographically, Fatumnasi sub-district is at an altitude of 1200-1800 dpl. Geonologically fatumnasi subdistrict is to the north bordering TTU Regency, to the south bordering North Mollo Sub-District, to the east bordering Tobudan Sub-district to the west with Nunbena sub-district and Kupang Regency. The area is at an altitude of 1200-1800 above sea level with an average temperature of $20 \mathrm{C}$ and a humid tropical climate. The area of Fatumnasi sub-district is $195.65 \mathrm{~km} 2$ which is divided into forest areas of fatumnasi nature reserves and residential areas. The settlement area is divided into 5 villages namely Fatumnasi Village, Nenas Village, Mutis Village, Kuanoel Village, and Nuapin Village. The percentage of the area of each village is Fatumnasi Village $17.97 \%$, Nenas Village 30.09\%, Nuapin Village $28.72 \%$, Kuanoel Village $17.63 \%$ and Mutis Village 5.63\%.

The most populous population is in Nuapin Village area of $32 \%$ or 2,249 people while the population is not densely populated in Mutis Village by $8 \%$ or 570 people of the total population of Fatumnasi Sub-district. The population distribution for one $\mathrm{Km} 2$ fatumnasi area is 45 people, Nenas Village 21, Nuapin Village 40, Kuanoel Village 32, and Mutis Village 52. The most populous population is in Mutis Village and the lowest spread is in Nanas Village. The livelihood of fatumnasi sub-district people is as farmers in the garden and farmers about $89 \%$ and the rest as traders, souvenir businesses, tour guides, civil servants and others.

The education level of most of fatumnasi village is at the 9year elementary education level where $47 \%$ is high school and $35 \%$ elementary school or $82 \%$ of the total population, while the higher school education level / vocational school is $14 \%$, then college education is only $2 \%$ for diplomas and $0.9 \%$ for undergraduates. This can be due to the lack of facilities and infrastructure of primary and secondary education in Fatumnasi Regency which currently has only 8 elementary schools, 2 junior high schools and 1 vocational high school. For alternative levels of high school education, diploma and bachelor's degree, people should look outside fatumnasi subdistrict.

The number of households using electricity in 2016 was 214 households with the highest percentage in Kuanoel Village at $7.46 \%$ or 116 out of a total of 1,555 households in the district. Followed by Fatumnasi Village with 88 FAMILIES or about $5.6 \%$. The lack of community electricity users can result in a slowdown in people's economic activities at night even though the availability of electricity advice is very influential in the management of a tourist village. The economic wheels of 
Fatumnasi sub-district are determined by several activities in the fields of plantation, agriculture and livestock. This is due to the large livelihoods of people in agriculture and livestock. The farmland is mostly planted with crops and horticulture such as rice, cassava, corn, highland vegetables (carrots, mustard, potatoes, etc.) as well as citrus fruits, strawberries and other types of highland fruits.

\section{DISCUSSION}

\section{A. Strengths - $S$}

- Located in the protected area of Mutis Mountain.

- The availability of natural attractions and culture is very natural.

- People have great respect for the natural environment through pao nasi culture which means a ban on encroachment on forest areas.

- At an altitude of 2100 above sea level with an average temperature of $15-20^{\circ} \mathrm{C}$.

- Pokdarwis fatumnasi village has been formed.

- Has formed a community association that cares about tourism or Nan Fain Isu.

- 30-bedroom homestay available.

- The culture of the community is still well maintained.

B. Weaknesses $-W$

- People's economic activities are dominated by plantation and livestock sectors.

- Low quality of human resources.

- Destination management not yet available.

- Public awareness of tourist villages is still lacking.

- Internet network is still low and there are still many areas of no network.

- Tourist Information Center (TIC) not yet available.

- Tour packages are privately managed by 1 local guide.

- No tourist village rules yet.

- No restaurant managed by the community.

- Tour packages sold dominated by BPW from outside the village.

C. Opportunities $-O$

- The NTT Provincial Government designated it as one of the plantation tourism development areas and received rp 1.2 billion in funding.

- Branding NTT as a Beauty Ring.
- Branding Fatumnasi as Swiss Suer.

- Now trending rural tourism especially in the millennial era.

- Village Tour through a virtual tour.

- Accommodation and tour packages in Fatumnasi village are very cheap.

- Reduced mass tourism activity in Fatumnasi Village. There is a commitment from the village government and the community to implement CBT.

- Establishment of community cooperation with other pentahelix tourism.

D. Threats $-T$

- There is a Covid-19 pandemic.

- Competitor tour packages are promoted through virtual tours.

- Turn tourist trends into individual tours from mass tourism.

- Traveller behavior changes through the application of health protocols

- Tourism industry era 4.0.

- Degradation of local culture due to cultural assimilation from outside the village.

- Foreign exchange leakage occurred due to lack of community participation in tourism economic activities.

Based on the results of internal factors and external factors above, SWOT strategy can be described as follows:

\section{E. Strategy $\mathrm{S}-\mathrm{O}$}

1) Realizing the brand image of sustainable communitybased tourism villages. (S1. S2. S3. S4. S5. S6) (O1.02.03.08.09) can be done through:

- Implement FGD between the community and the village government to build brand image or brand awareness of Fatumnasi tourism village.

- Brand image determination through SK Kepala Desa together with tourism aware groups and other communities.

- The application of this brand image is carried out on the principle of not contrary to the customs or culture of fatumnasi community, physical coaching to improve the quality of the village environment, not damaging, paying attention to local elements and authenticity, paying attention to the supporting capacity and insight of the environment. 
2) Develop nature-based and local tourism attractions. (S6. S7. S8. S9.) (O4. O6) can be done through:

- Fatumnasi Tourism Village Zoning consisting of Natural Tourism Area, Trekking, Adventure Tourism, Ecotourism, Educational Tourism including Local Food and Weaving, Agro Tourism and Cultural Tourism.

- It involves art galleries in dawan cultural performances in each tour package.

- Engage art galleries in dawan cultural performances in each tour package.

3) Improving the marketing strategy of Fatumnasi tourism village. (S6. S7. S8) (O5. O8. O9) can be done through:

- The creation of superior product value for tourist villages.

- Set a standard rental price for accommodation.

- Offering tour packages through social media containing tour itinerary containing a list and schedule of tour events with complete data on the day, date, time of place (object) of tourism, homestay or house of residents where to stay, place of departure, place of arrival, activities that tourists will do by involving the participation of the community.

\section{F. Strategy $W-O$ :}

1) Improving the entrepreneurial spirit of the community in the field of tourism (W1. W2. W4. W5. W6. W8. W9, 2015/ W.10) (O6.08) can be done through:

- Strengthening the entrepreneurial spirit of the community through training and rolling capital from the use of grants from the Provincial Government amounting to $\mathrm{Rp} 1.2$ billion. Increasing the role of BUMDES in Fatumnasi Village in the development of tourist villages through the allocation of special funds for training and revolving funds for homestays and others. For this reason, the fatumnasi village government in designing the use of village budget funds focuses on the development of tourist villages. Increase community participation in creative economic activities through the provision and opening of various Ancillararies (supporting facilities) which include souvenir shops, food stalls, pulse stalls, food stalls, bicycle rentals, camping equipment rentals, internet stalls, internet stalls, dance venues and community cultural performances.

- To build the institution of tourism village management through the TTS District Regent's Decree.

- Creating accessibility of internet network through the proposal of telkomsel tower addition and additional bandwidth so that blank spot area is no longer available.

- Improving the condition of road access to Fatumnasi tourist village through improved road status from district roads to provincial roads and country roads. This funding can be done through the provision of special allocation from the district or provincial Public Works Office.

2) Establishing the institutional management of the village village. (W2. W3. W4. W8) (O1. O8. O9).

3) Creating smooth accessibility to tourist villages (W3. W5. W6.) (O1. O3. O4. O5).

4) Build a marketing network with travel agency partners (W7. W10) (S6. S7) (O1. O2. O3. O9).

\section{G. Strategy $S-T$}

- Implement kemenpar health protocol standards in destinations based on Clean, Healthy and Safety or CHS (S2) programs. S3. S6. S7. S8. S9) (T1. T3. T4.).

- Sell village tourism products through virtual tour (S1. S2. S4. S6. S7) (T1. T2. T5. T7).

- Applying homestay product certification (S6. S7. S8.) (T1. T3. T4. T7)

\section{H. Strategy $W-T$}

- Improving community competence in the field of tourism village management (W1. W2. W4. W8) (T2. T3. T5. T6. Q7)

- Open tourist information center or tic (W5. W6. W7) (T2. T3. T5. Q.6).

- Apply sapta charm (W2. W3. W4) (T1. T4. T6).

\section{CONCLUSION}

- Fatumnasi Tourism Village is one of seven tourist area locations that have been designated by the Government of East Nusa Tenggara as many as $90 \%$ of Fatumnasi villagers strongly agree to implement community-based tourism.

- As many as $90 \%$ of Fatumnasi villagers strongly agree to implement community-based tourism.

- S-O strategies include the creation of a tourism village brand image, the development of natural tourism and local culture attractions, and the improvement of fatumnasi tourism village marketing strategy.

- W-O's strategies include increasing the entrepreneurial interest of the community, building the institutional governance of rural villages, creating internet accessibility and road networks, and building marketing networks.

- S-T strategies include the implementation of lean protocol standards, Healthy and Safety or CHS, the sale of village tourism products through virtual tours, and the implementation of tourism product certification in the field of homestay. 
- W-T's strategy includes improving community competence in the field of tourism village management, the opening of tourist information centers (TIC), and the promotion of tourism aware movements with sapta pesona program

\section{REFERENCES}

[1] E. Inskeep, Tourism Planning, and Integrated and Sustainable Development Approach. New York: Van Nostrand Reinhold, 1991

[2] D. Pearce, Tourism a Community Approach, $2^{\text {nd }}$. Harlow Longman, 1995.

[3] W. Nuryanti, Concept, Perspective and Challenges, part paper from the International Conference Report on Cultural Tourism. Yogyakarta:Gadjah Mada University Press, 1993, pp. 2-3.

[4] B. Dude, Qualitative Research Methodology. Jakarta: PT RajaGrafindo Persada, 2010.
[5] H. Kustini, "Analisis Potensi Wisata Terhadap Pengembangan Kampung Wisata Sewu Kembang Di Nglurah, Karanganyar,” Jawa Tengah. Jurnal Hotelier, vol. 5, no. 1, pp. 79-89, 2019.

[6] H. Goodwin and R. Santili, "Community-based Tourism," ICRT Occasional Paper 11, 2009.

[7] P. Suansri, Community Based Tourism Handbook. Thailand: Responsible Ecological Social Tours (REST) Project, 2003.

[8] D.J. Timothy, "Participatory Planning a View of Tourism In Indonesia," Annals of Tourism Research, vol. 26, no. 2, pp. 371-391, 1999.

[9] S.B. Tandilino and P.M. Meko, "Penerapan Community Based Tourism Di Desa Wisata Lamalera B Dalam Mendukung Pariwisata Estate Di Nusa Tenggara Timur," TOURISM: Jurnal Travel, Hospitality, Culture, Destination, and MICE, vol. 3, no. 1, pp. 14-25, 2020.

[10] D.R. Sugiyono, Metode penelitian administrasi. Bandung: Alfabeta, 2002.

[11] S. Arikunto, Metode Penelitian Tindakan Kelas. Jakarta: Rineka Cipta, 2007. 